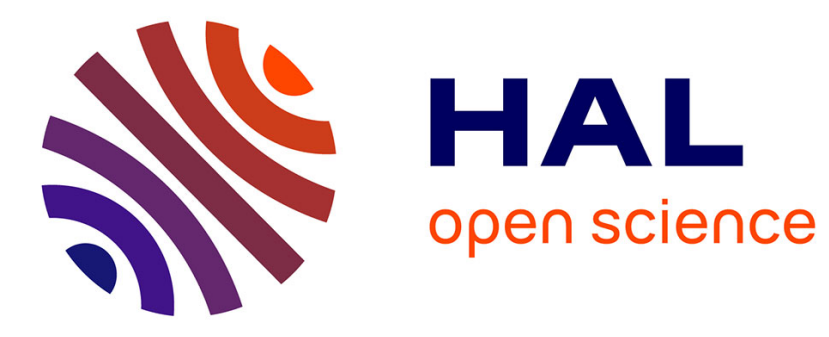

\title{
Synthesis of Spongidepsin and Analogs
}

\author{
Laurent Ferrié, Ondine Picot, Amandine Guérinot, Janine Cossy
}

\section{To cite this version:}

Laurent Ferrié, Ondine Picot, Amandine Guérinot, Janine Cossy. Synthesis of Spongidepsin and Analogs. European Journal of Organic Chemistry, 2020, 10.1002/ejoc.202001009 . hal-02973074

\section{HAL Id: hal-02973074 \\ https://hal.science/hal-02973074}

Submitted on 20 Oct 2020

HAL is a multi-disciplinary open access archive for the deposit and dissemination of scientific research documents, whether they are published or not. The documents may come from teaching and research institutions in France or abroad, or from public or private research centers.
L'archive ouverte pluridisciplinaire HAL, est destinée au dépôt et à la diffusion de documents scientifiques de niveau recherche, publiés ou non, émanant des établissements d'enseignement et de recherche français ou étrangers, des laboratoires publics ou privés. 


\title{
Synthesis of Spongidepsin and Analogs
}

\author{
Laurent Ferrié,${ }^{[b]}$ Ondine Picot, ${ }^{[a]}$ Amandine Guérinot ${ }^{[a]}$ and Janine Cossy ${ }^{\star[a]}$
}

[a] O. Picot, Dr. A. Guérinot, Prof. J. Cossy

Molecular, Macromolecular Chemistry and Materials

ESPCI Paris, PSL University, CNRS, 75005 Paris, France.

E-mail: janine.cossy@espci.fr

https://www.Ico.espci.fr/-Prof-Janine-Cossy-

[b] Dr. L. Ferrié

BioCIS, Faculté de Pharmacie, Université Paris-Saclay

5 rue J. B. Clément 92290 Châtenay-Malabry, France

Abstract: Seven syntheses of (-)-spongidepsin, a natural product isolated from Spongia $s p$. with moderate antiproliferative activity, are described and the different analogs obtained during these syntheses are reported. A comparison between the different syntheses has been achieved.

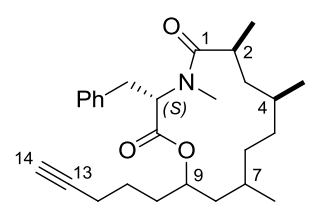

(-)-Spongidepsin

(originally reported structure)

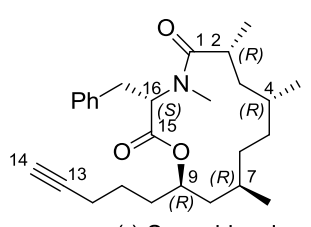

(-)-Spongidepsin

(revised structure after total synthesis)

\section{Introduction: Isolation, Structural Determination and Biological Activity}

Spongidepsin is a natural product, which was isolated from a marine sponge Spongia sp. (family Spongidae, class Demospongiae) collected off the Vanuatu Island in the Pacific Ocean by Riccio et al. in 2001. ${ }^{[1]}$ Spongia genus is a natural source of diterpenoids and polypropionates such as, for example epi-spongiadiol $^{[2]}$ and spongistatine. ${ }^{[3]}$ Spongidepsin was isolated from $\mathrm{CCl}_{4}$ fractionation of methanolic extract of the sponge. Further purification by medium pressure liquid chromatography on silica gel followed by a final purification using a reverse phase HPLC afforded spongidepsin $(1.4 \mathrm{mg}$ from $500 \mathrm{~g}$ of dried sponge) as a colorless solid.

Spongidepsin has a unique and non-common structure, which encompasses a 13-membered macrolide with five stereogenic centers, one of them belonging to a phenylalanine motif and the other four ones being present in a ketide motif. In addition, and very surprisingly, a side chain with a terminal alkyne is present. The absolute $(S)$-configuration of the carbon present in the $\mathrm{N}$-methyl-phenylalanine motif was established by Marfey analysis on the product resulting from the acidic hydrolysis of spongidepsin. ${ }^{[1,4]}$ The syn-relationship between the two methyl substituents at $\mathrm{C} 2$ and $\mathrm{C} 4$ was established by utilizing Murata's NMR spectroscopic method, ${ }^{[1,5]}$ however the absolute configuration of the carbons could not be established. On the contrary, the configuration of the stereogenic centers at C7 and C9 could not be determined by NMR spectroscopy due to an overlap of the signals in the ${ }^{1} \mathrm{H}$ NMR spectra. Thus, a total number of eight diastereomers for the natural spongidepsin was possible! The only way to establish the absolute configuration of the stereogenic centers was, at this time, to synthesize the eight diastereoisomers and to compare their analytical data to the analytical data of the natural product. This synthetic work was realized by Forsyth et al. in 2004 and the assignment of the absolute configuration of the stereogenic centers of the natural spongidepsin revealed to be $(2 R, 4 R, 7 R, 9 R, 16 S) .{ }^{[6]}$ The structure was then confirmed shortly after by Ghosh et al. (Figure 1). ${ }^{[7]}$

Figure 1. Originally assigned and revised structure of (-)-spongidepsin

From a biological point of view, spongidepsin has shown a moderate antitumoral activity against cancer cell lines J774.A1 (lymphatic cells from mouse), HEK-293 (human kidney cells) and WEHI-164 (fibrosarcoma from mouse), the $\mathrm{IC}_{50}$ being respectively $0.56,0.66$ and $0.42 \mu \mathrm{M} .{ }^{[7]}$ Unfortunately, the limited resources of spongidepsin from Nature did not allow an extensive screening of the biological activity on multiple targets.

Due to its original structure and potential biological activities, spongidepsin attracted several chemists specialized in total synthesis. The rest of the review will focus on the different strategies involved in the total synthesis of spongidepsin to control the different stereogenic centers; in particular, a differentiation will be made between the catalytic and the stoichiometric methods.

Laurent Ferrié graduated from Université de Lyon, and then moved, in 2004, to Paris at the ESPCl to complete his PhD under the supervision of Prof. Janine Cossy. In 2008, he joined Prof. Peter Wipf at the University of Pittsburgh (USA) for a postdoctoral internship and was hired in 2009 at CNRS, in BioCIS, at Université Paris-Sud/ParisSaclay. His research interests focus on natural product total synthesis, synthesis of endoperoxides and discovery of new drug candidates for the treatment of the Parkinson's disease. 
Ondine Picot was born in 1994 in Aubergenvilles (France). She obtained her master degree in 2016 (Université Pierre et Marie Curie), graduated from ENS-Cachan and received an engineer degree from Chimie-ParisTech in 2017. Then she started her $\mathrm{PhD}$ thesis under the supervision of Prof. Janine Cossy and Dr. Amandine Guérinot, on the development of an enantioselective homoallylation of aldehydes and its application towards the total synthesis of (-)-spongidepsin

Amandine Guérinot was born in 1983 in Troyes, France. She graduated as chemical engineer from ESPCI Paris in 2007 and received her $\mathrm{Ph}$. D. in 2010 from the University Pierre et Marie Curie under the supervision of Dr. Sébastien Reymond and Prof. Janine Cossy. She joined the group of Prof. Sylvain Canesi at UQAM, Montreal as a postdoctoral associate and then moved to

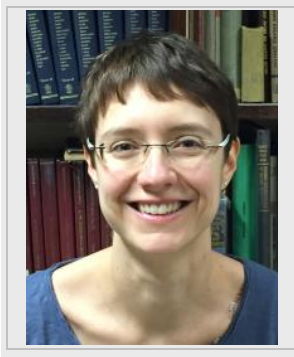
ICMMO, Orsay, France for a one-year postdoctoral stay with Prof. Vincent Gandon. After a six months postdoctoral fellowship with Dr. Laurent Micouin (Paris Descartes University), she was appointed Associate Professor in 2013 at ESPCI Paris. Her research interests include organometallic cross-couplings, sustainable catalysis, synthesis of biologically active compounds and dynamic covalent chemistry.

Janine Cossy did her undergraduate and graduate studies at the University Champagne-Ardenne in Reims under the supervision of Prof. Pète. After a postdoctoral stay with Prof. Trost, at the University of Wisconsin (USA), she returned to Reims where she became, in 1990, DR CNRS. In the same year, she moved to Paris where she was appointed Professor of Organic Chemistry at the ESPCI Paris. Janine

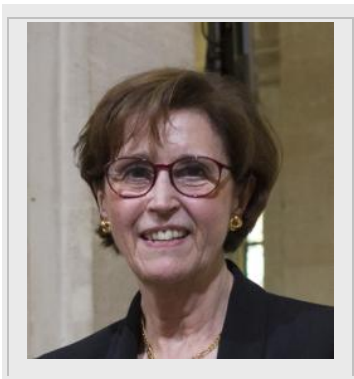

Cossy's research interests focus on the synthesis of natural products and/or biologically active molecules and on the development of synthetic methods. Her research efforts have resulted in more than 525 publications and 17 patents.

\section{Syntheses of Spongidepsin}

Up to now, seven syntheses and one synthetic approach of spongidepsin have been reported. For the global disconnections all the syntheses are utilizing the strategy of Forsyth et al., who were the first to report the synthesis of (-)-spongidepsin However, the methods used to control the absolute configuration of the stereogenic centers at C2, C4, C7 and C9 are different, and are either controlled by the substrate or by the reagent used in stoichiometric or catalytic quantities.

\subsection{Control of the Stereogenic Centers by Reagents Used in Stoichiometric Amount}

\subsubsection{Forsyth et al. Total Synthesis}

In order to determine the absolute configuration of the four stereogenic centers, the (S)-absolute configuration of the phenylalanine motif being already known, Forsyth et al developed a stereodivergent synthesis of spongidepsin ${ }^{[6]}$ allowing the access to the eight possible diastereomers. As their synthesis was realized according to the same strategy, only the synthesis of the natural diastereomer will be described. Forsyth et al. have envisaged a convergent synthesis of spongidepsin from three fragments: (S)- $N$-methyl- $N$-Boc phenylalanine I, alcohol II and carboxylic acid 8. A Mitsunobu reaction was used to assemble fragments $\mathbf{I}$ and II and an amidation allowed the formation of the $\mathrm{N}-\mathrm{C} 1$ bond. The 13-membered ring of (-)-spongidepsin was constructed by using an olefin ring-closing metathesis (RCM). It is worth mentioning that a stereodivergent strategy has been used to prepare fragment II in order to access all the possible eight diastereomers. By synthesizing the eight diastereomers, the absolute configuration of the spongidepsin stereogenic centers could be established and revealed to be $(2 R, 4 R, 7 R, 9 R, 16 S)$ (Scheme 1).

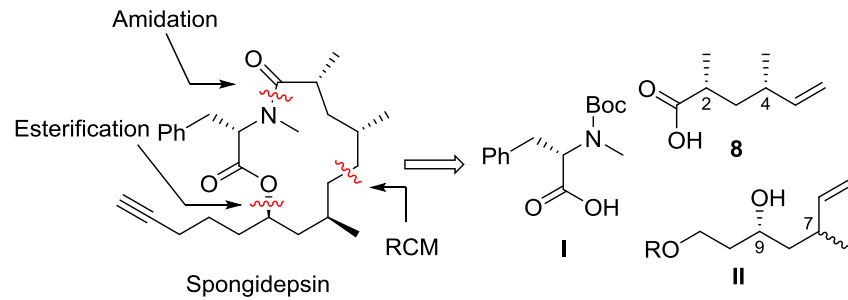

Scheme 1. (-)-Spongidepsin retrosynthetic analysis by Forsyth et al.

Carboxylic acid $\mathbf{8}$ was prepared from meso-diol $\mathbf{4}$. As the latter is not commercially available, it was synthesized from malonate 1 and methacrylate 2 in six steps via cyclic anhydride $\mathbf{3}$, which furnished meso-cyclic anhydride 3' after a selective crystallization. ${ }^{[8,9]}$ After reduction by $\mathrm{LiAlH}_{4}$, 3' was transformed to meso-diol 4, which was desymmetrized by an enzymatic acylation $^{[10]}$ to furnish monoacylated diol $5(72 \%$, ee > 97\%) After a protection/deprotection sequence followed by an oxidation, the obtained aldehyde was converted into alkene 7 by using Lombardo's olefination conditions. ${ }^{[11]}$ Desilylation of $\mathbf{7}$, followed by Jones oxidation of the resulting alcohol led to the desired carboxylic acid 8 (56\%) (Scheme 2). 


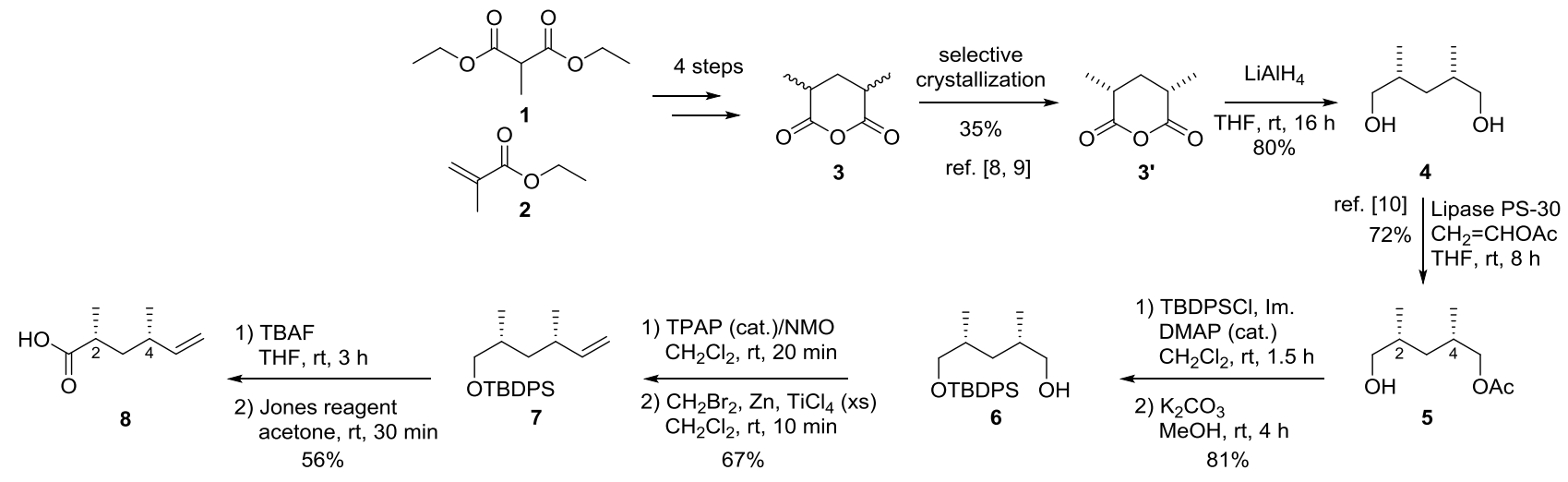

Scheme 2. Synthesis of carboxylic acid 8 by Forsyth et al. TBDPS = tert-butyldiphenylsilyl, Im. = imidazole, DMAP = dimethylaminopyridine, TPAP = tetrapropylammonium perruthenate, $\mathrm{NMO}=\mathrm{N}$-methyl morpholine oxide, TBAF = tetrabutylammonium fluoride.

The C6-C11 fragment II was synthesized from optically active epoxyde 9, bearing the C9 stereogenic center. This epoxide, prepared from L-malic acid, ${ }^{[12]}$ was ring-opened by isopropenyl magnesium bromide in the presence of a catalytic amount of Cul. The resulting secondary alcohol was converted into TES-ether 10 and, after a hydroboration/oxidation sequence, diastereomers 11 and 11' were isolated as an equimolar mixture, which could not be separated by column chromatography. However, the authors had anticipitated that the $\mathrm{C} 7$ epimers would be separated later, at the stage of the conformationally constrained 13-membered macrolide resulting from the RCM. The diastereomeric mixture of alcohols was thus converted to olefins $12 / 12$ ' through an oxidation ${ }^{[13]} /$ olefination/deprotection sequence (74\% over three steps). Having the three fragments in hand, the assembly of these fragments was achieved. The coupling of $12 / 12$ ' with (S)- $N$-methyl- $N$-Boc phenylalanine I was realized by using a Mitsunobu reaction ${ }^{[14]}$ to introduce the C9 stereogenic center with inversion of configuration affording the esters 13/13' in an equimolar ratio. Cleavage of the $N$-Boc carbamate, using TBSOTf, followed by the addition of TBAF, led to 14/14' (82\%, two steps). Two steps were necessary to access the 13membered macrocycle, e.g. an amidation of the carboxylic acid 8 with amines $14 / 14^{\prime}(87 \%)^{[15]}$ and then treatment of the resulting amides $15 / 15$ ' with the second generation Grubbs catalyst ${ }^{[16]}$ in refluxing toluene, affording a mixture of unsaturated macrocyclic epimers at $\mathrm{C} 7$ with predominant $E$-alkenes $(E / Z=10: 1)$. At this stage, as expected, the $\mathrm{C} 7$ epimers were separated by flash chromatography and after hydrogenation, 16 was isolated $(35 \%)$. To complete the synthesis of (-)-spongidepsin, four additional steps were necessary. First, the primary alcohol was transformed to an iodide, which was then allylated by treatment with allyl tri- $n$-butylstannane. The resulting olefin underwent an oxidative cleavage, and the resulting aldehyde was involved in a Bestmann-Ohira reaction (46\% over 4 steps) ${ }^{[17]}$ to introduce the required terminal alkyne and complete the synthesis of $(-)$-spongidepsin with the $(2 R, 4 R, 7 R, 9 R, 16 S)$ configurations The obtained 13-membered macrocycle spectroscopic data $\left[{ }^{1} \mathrm{H}\right.$ NMR and ${ }^{13} \mathrm{C}$ NMR spectra, HRMS] matched those of natural spongidepsin as well as optical rotation $\left[[\alpha]_{D}-67.5\right.$ (c 1.0, $\mathrm{MeOH})$; natural product: $\left.[\alpha]_{D}-61.8(c 1.4, \mathrm{MeOH})\right]$ (Scheme 3). 


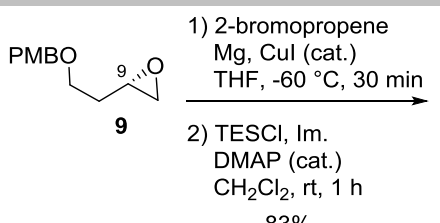

$83 \%$

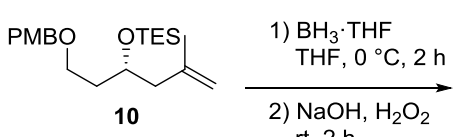

10

2) $\mathrm{NaOH}, \mathrm{H}_{2} \mathrm{O}_{2}$

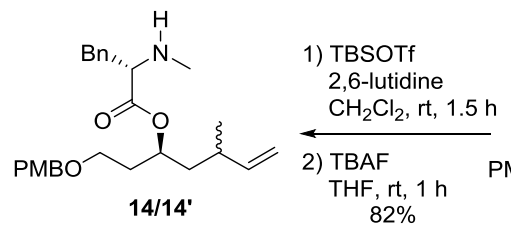

$$
14 / 14
$$
$82 \%$

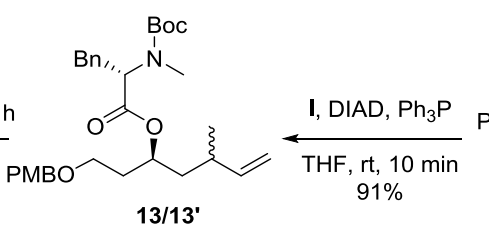

13/13'

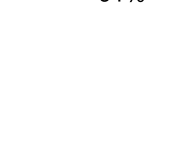

(1)

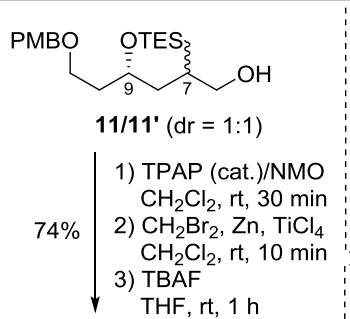

12/12'

\begin{tabular}{l|l}
$87 \%$ & $\begin{array}{l}\text { 8, PyAOP, DIPEA } \\
\text { DMF, rt, } 24 \mathrm{~h}\end{array}$
\end{tabular}

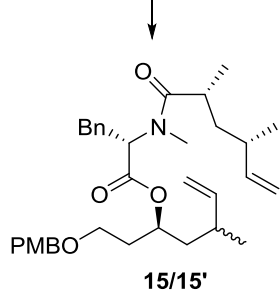

1) G-II (cat.) Toluene, $110^{\circ} \mathrm{C}$ $20 \mathrm{~min}$ 2) separation 3) $\mathrm{H}_{2}, \mathrm{Pd} / \mathrm{C}$ (cat.) EtOAc, rt, $8 \mathrm{~h}$ $35 \%$

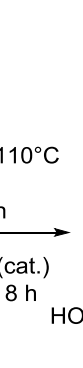<smiles>C1CCCC1</smiles>

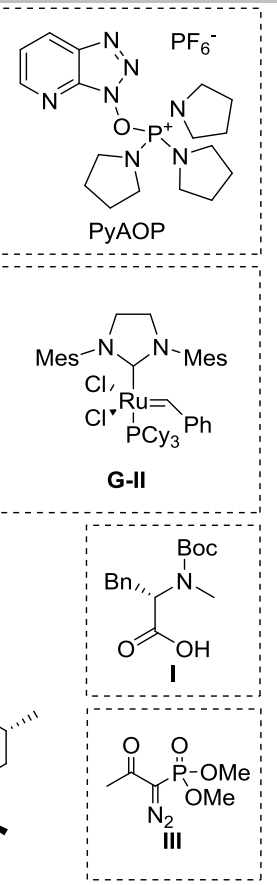

Scheme 3. Synthesis of the C6-C11 fragment and end game to $(-)$-spongidepsin by Forsyth et al. PMB = para-methoxybenzyl, TES = triethylsilyl, Im. = imidazole, $\mathrm{DIAD}=$ diisopropyl azodicarboxylate, $\mathrm{TBS}=$ tert-butyldimethylsilyl, Boc = tert-butyloxycarbonyl, DIPEA = diisopropylethylamine, $\mathrm{DMF}=$ dimethylformamide, $\mathrm{AIBN}$ =azobisisobutyronitrile.

\subsubsection{Ghosh and $X u$ Total Synthesis}

A few months later, after the reported synthesis of spongidepsin by Forsyth et al., Ghosh and Xu published a synthesis of spongidepsin and four of its possible diastereomers, confirming the absolute configuration of the stereogenic centers of natural (-)-spongidepsin. ${ }^{[7]}$ The same convergent strategy as Forsyth et al. was used to produce (-)-spongidepsin. As previously described, carboxylic acid 8 was prepared from meso-diol $\mathbf{4}^{[18]}$ using an enzymatic desymmetrization and then, a similar sequence of reactions to the ones utilized by Forsyth et al. was applied to mono-acetylated diol $\mathbf{5}$ to obtain carboxylic acid $\mathbf{8}$ [Wittig olefination instead of a Lombardo olefination then deprotection and oxidation to carboxylic acid (cf Scheme 2)].

Ghosh et al. have synthesized the C6-C13 fragment instead of the $\mathrm{C} 6-\mathrm{C} 11$ fragment reported by Forsyth et al. The synthesis started with commercially available pent-4-en-1-ol, which was protected and involved in an olefin cross-metathesis reaction ${ }^{[19]}$ with allyl chloride to afford, after a halogen exchange (Nal, acetone), allylic iodide 17 as a $E / Z$ mixture in a $15: 1$ ratio (61\% over three steps). To control the $\mathrm{C} 7$ stereogenic center, this allyl iodide was methylated according to an Evans' asymmetric alkylation ${ }^{[20]}$ of oxazolidinone IV affording 18 with an excellent diastereomeric excess of $96 \%$ and a very good yield $(90 \%)$. To control the stereogenic center at C9, oxazolidinone 18 was involved in a diastereoselective bromolactonization (the diastereomeric ratio was not indicated), by applying the Bradbury's protocol. ${ }^{[21]}$ After debromination, ${ }^{[22]}$ the obtained lactone $\mathbf{2 0}$ was reduced to the corresponding lactol with DIBAL$\mathrm{H}$, which was at that point involved in a Wittig olefination to give alkene 21 (74\%). The three fragments I, 8 and 21 were then assembled. A Mitsunobu reaction between alcohol 21 and carboxylic acid I was used to form ester 22 (73\%). After cleavage of the carbamate, the resulting amine was condensed with carboxylic acid 8 and the obtained diene 23 (86\%) was converted to 13-membered macrocycle 24 featuring a (Z)-double bond by treatment with the G-II catalyst. After a deprotection/hydrogenation/oxidation sequence, the resulting aldehyde was treated with Ohira-Bestmann reagent III $^{[23]}$ to afford (-)-spongidepsin (Scheme 4). It is worth noting that Ghosh et al. have synthesized four diastereomers of (-)-spongidepsin using the same chemical sequences (cf. Scheme 12). 

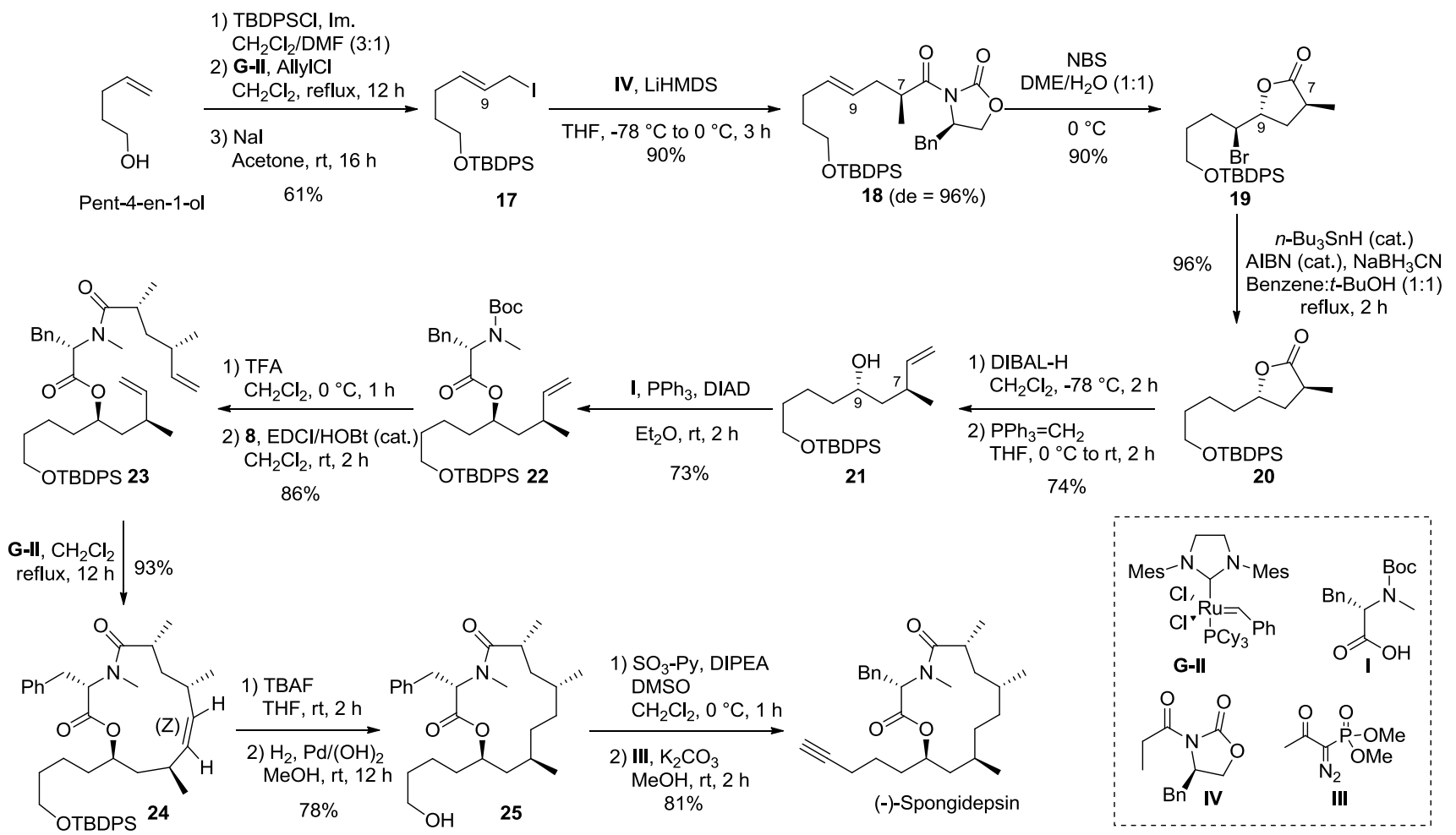

Scheme 4. Synthesis of the C6-C13 fragment and end game to (-)-spongidepsin by Ghosh and Xu. TBDPS = tert-butyldiphenylsilyl, Im. = imidazole, HMDS= hexamethyldisilazane, NBS $=\mathrm{N}$-bromosuccinimide, DME = dimethoxyethane, DIBAL-H = diisobutylaluminium hydride, DIAD = diisopropyl azodicarboxylate, TFA = trifluoroacetic acid, $\mathrm{EDCl}=$ 1-ethyl-3-(3-dimethylaminopropyl)carbodiimide, $\mathrm{HOBt}=$ hydroxybenzotriazole, TBAF = tetrabutylammonium fluoride, $\mathrm{Py}=$ pyridine DMSO = dimethylsulfoxide

\subsubsection{Cossy et al. Total Synthesis}

Two years after the syntheses of (-)-spongidepsin, reported by Forsyth et al. and Ghosh and Xu, Cossy et al. published the third synthesis of (-)-spongidepsin. The general strategy, utilizing a Mitsunobu reaction to realize the esterification and a RCM to build up the 13-membered macrocycle, was used. ${ }^{[24]}$ The synthesis of carboxylic acid $\mathbf{8}$ was improved compared to the previous syntheses in terms of steps and overall yield. Indeed, the synthesis of $\mathbf{8}$ started with the commercially available (+)-Roche ester which, after a protection/reduction sequence, was transformed into aldehyde $26^{[25]}(88 \%)$. This latter was submitted to a crotylstannylation ${ }^{[26]}$ to produce syn,syn- and syn, anti-stereotriads $\mathbf{2 7}$ and $\mathbf{2 7}$ ' in a 87:13 ratio (syn,syn/syn, anti $=87: 13,76 \%$ ) via transition state A. After the separation of the two diastereomers, $\mathbf{2 7}$ was converted to unsaturated alcohol $\mathbf{2 9}$ by deoxygenation through a mesylation/reduction $\left(\mathrm{LiAlH}_{4}\right)$ sequence followed by the cleavage of the silyl ether $(65 \%$ over three steps). An oxidation utilizing the Jones reagent, afforded carboxylic acid 8 (72\%). Carboxylic acid 8 was obtained in seven steps from the (+)-Roche ester with an overall yield of $31 \%$ (Scheme 5).

The stereoselective synthesis of the $\mathrm{C} 6-\mathrm{C} 13$ fragment started with 5-hexen-1-ol, which was transformed into aldehyde 30 after protection of the hydroxy group and ozonolysis. ${ }^{[27]}$ One of the crucial step to access (-)-spongidepsin is the synthesis of lactone 32, which relies on an intermolecular stereoselective condensation of a ketyl radical on the optically active a, $\beta$-unsaturated ester $31,{ }^{[28]}$ mediated by $\mathrm{Sml}_{2}(35 \%$, er $=$ $85 / 15){ }^{[29]}$ The resulting lactone was stereoselectively methylated $(\mathrm{dr}=85: 15,65 \%)$ and, after reduction of lactone 20 by DIBAL-H, the resulting lactol was submitted to a Wittig olefination, affording 21, which corresponds to the C6-C13 fragment (55\%) (Scheme 6). 


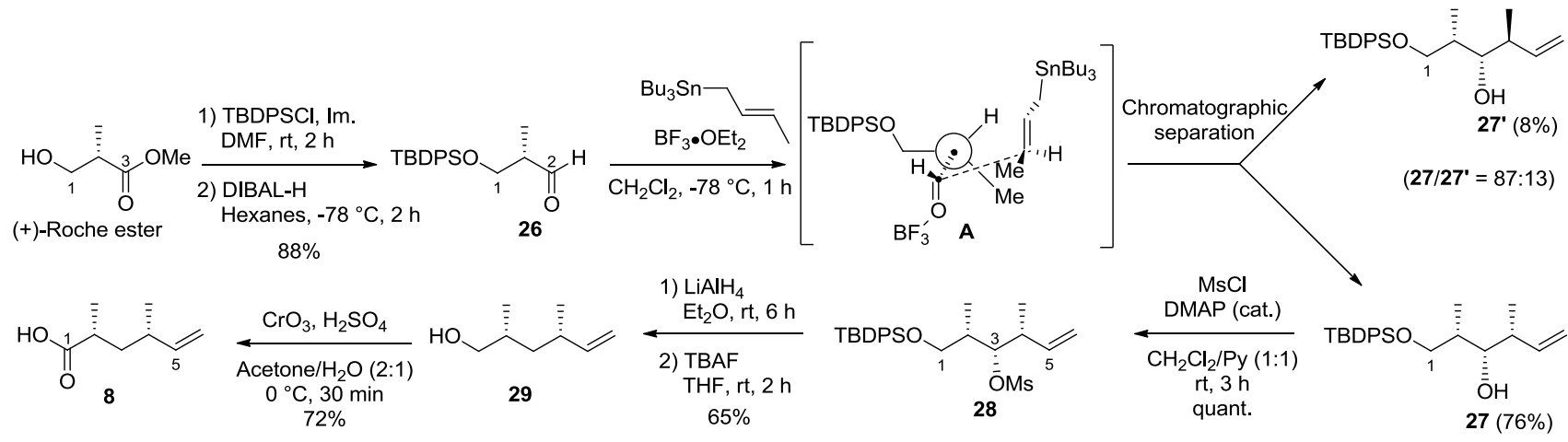

Scheme 5: Synthesis of the carboxylic acid 8 from the (+)-Roche ester by Cossy et al. TBDPS = tert-butyldiphenylsilyl, Im. = imidazole, DIBAL-H = diisobutylaluminium hydride, $\mathrm{DMF}=$ dimethylformamide, $\mathrm{Ms}=$ methanesulfonyl, $\mathrm{DMAP}=$ dimethylaminopyridine, $\mathrm{TBAF}=$ tetrabutylammonium fluoride .

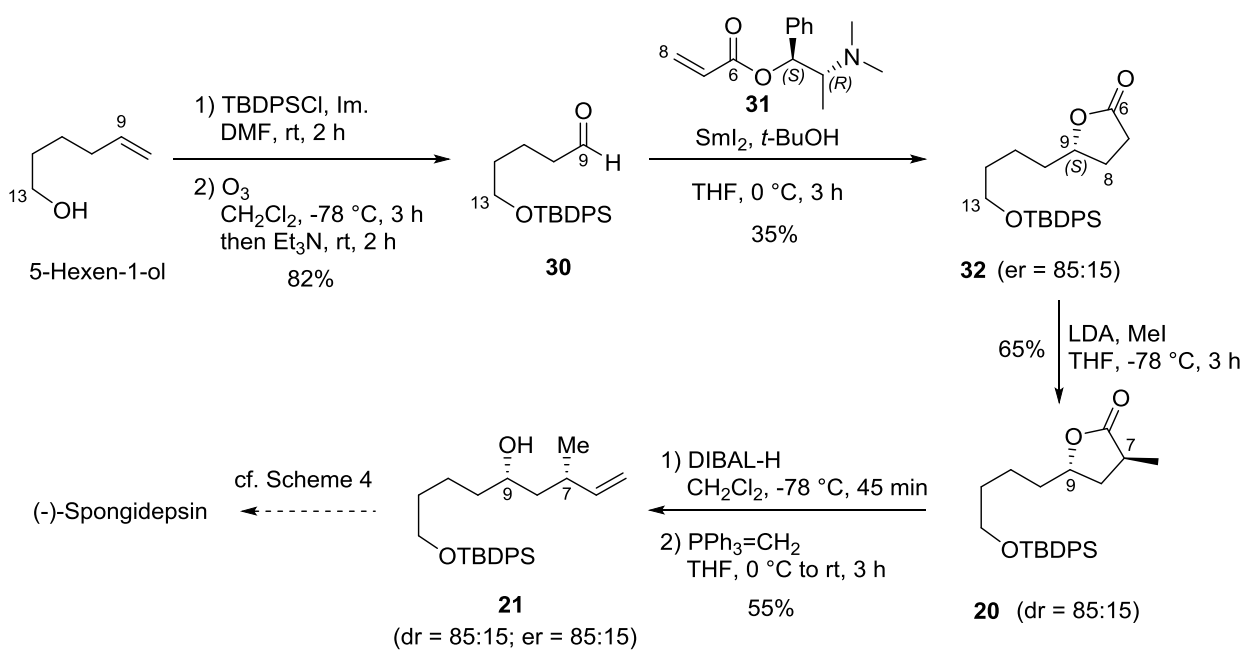

Scheme 6. Synthesis of the C6-C13 fragment by Cossy et al. TBDPS = tert-butyldiphenylsilyl, Im. = imidazole, LDA = lithium diisopropylamide, DIBAL-H = diisobutylaluminium hydride.

Compound $\mathbf{2 1}$ was then transformed into (-)-spongidepsin according to the same sequence of reactions used by Ghosh et al., except that the oxidation of the primary alcohol in 25 was realized with Dess-Martin periodinane rather than using ParikhDoering protocol.

\subsubsection{Chandrasekhar et al. Formal Synthesis}

Chandrasekhar et al. reported a formal synthesis of (-)-spongidepsin by synthesizing macrocycle 25. ${ }^{[30]}$ Carboxylic acid 8 was obtained in 12 linear steps from (+)-Roche ester, the C4 stereogenic center being controlled by the substrate. After a standard protection of $(+)$-Roche ester leading to 33 , an homologation to the $\alpha, \beta$-unsaturated ester $\mathbf{3 4}$ was achieved using a DIBAL-H reduction followed by a Wittig-Horner olefination $(78 \%)$. In order to introduce the C4 stereogenic center, two successive reductions were achieved (DIBAL-H, $\mathrm{CH}_{2} \mathrm{Cl}_{2}$ then $\mathrm{Pd} / \mathrm{C}$, EtOAc, $82 \%$ ). After oxidation of monoprotected diol $\mathbf{3 5}$ to an aldehyde, hydrazone $\mathbf{3 6}$ was prepared using (S)-1-amino-2-methoxymethyl proline (SAMP, 88\%). ${ }^{[31]}$

Therefore, a stereoselective alkylation with Mel, under basic conditions, produced 37 ( $d r=9: 1,92 \%)$. The oxidative cleavage of the hydrazone function by ozonolysis followed by a Wittig olefination of the resulting aldehyde led to alkene 7 (83\%, two steps). A deprotection of the hydroxyl followed by an oxidation step, led to desired carboxylic acid 8 (70\%) (Scheme 7).

To control the absolute configuration of the C9 stereogenic center, Chandrasekhar et al. performed an organocatalytic reaction, however $40 \mathrm{~mol} \%$ of the "catalyst" were used. The construction of the $\mathrm{C} 6-\mathrm{C} 13$ fragment started with the commercially available (-)-citronellol which, after protection of the primary hydroxy group and ozonolysis provided aldehyde $\mathbf{3 8}$ in $86 \%$ yield. The key stereoselective step was then the introduction of the hydroxy group at C9 according to McMillan $\alpha$ hydroxylation $^{[32-36]}$ of aldehyde 38 using nitrosobenzene and Dproline ( $40 \mathrm{~mol} \%$ ) in DMSO followed by a $\mathrm{NaBH}_{4}$ reduction. The resulting anilinoxy derivative was then treated with $\mathrm{CuSO}_{4}(30$ $\mathrm{mol} \%, \mathrm{MeOH}$ ) to cleave the $\mathrm{N}-\mathrm{O}$ bond and diol 39 was isolated in $53 \%$ yield with an excellent diastereoselectivity (de $=98 \%$ ). The 1,2-diol was converted to epoxide $\mathbf{4 0}$ in two steps (regioselective tosylation of the primary alcohol followed by basic treatment, 83\%), and the latter was selectively ringopened by the acetylenic organolithium reagent $\mathbf{V}$ to give compound 41. After an exhaustive hydrogenation and a protection of the secondary alcohol, a selective cleavage of the primary TBDPS ether over the secondary TBS ether was 
achieved with methanolic soda, ${ }^{[37]}$ affording 42 in $73 \%$ yield over three steps. Three more steps were necessary to access C6C13 fragment 43 , i.e. the substitution of the primary alcohol by an iodide followed by an elimination and the deprotection of the secondary alcohol (62\% over three steps). A Yamaguchi esterification $^{[38]}$ was then used to assemble $N$-methyl- $N$-Boc-Lphenylalanine I with 43. After cleavage of the $\mathrm{N}$-Boc protecting group (TBSOTf, 2,6-lutidine, then TBAF), the resulting amine was converted to diene $\mathbf{4 5}$ by amidation of $\mathbf{8}$ (68\% over three steps). Common to all strategies, a RCM was realized with G-II catalyst and, after a one-pot hydrogenation, macrocycle $\mathbf{2 5}$ was isolated $(80 \%)$. The synthesis of this intermediate constitutes a formal synthesis of (-)-spongidepsin (Scheme 8).

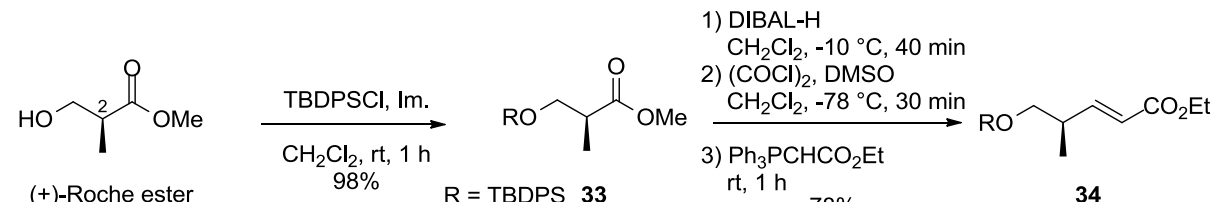

(+)-Roche ester

$\mathrm{R}=\mathrm{TBDPS} 33$

rt, $1 \mathrm{~h} 78 \%$

34

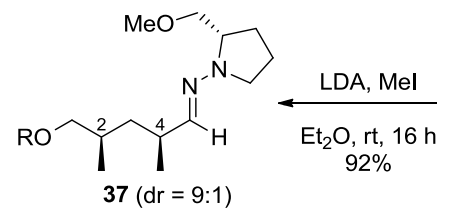

\begin{tabular}{l|l}
$83 \%$ & 1) $\mathrm{O}_{3}$ \\
$\mathrm{CH}_{2} \mathrm{Cl}_{2},-78{ }^{\circ} \mathrm{C}$
\end{tabular}

2) $t$ - $\mathrm{BuOK}, \mathrm{Ph}_{3} \mathrm{PCH}_{3}$

$\checkmark \mathrm{THF}, \mathrm{rt}, 1 \mathrm{~h}$

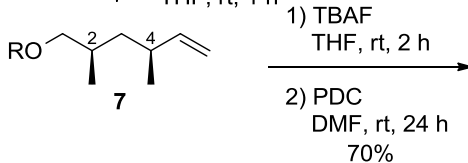

1) $\mathrm{IBX}$

DMSO/THF (1:3)

$\mathrm{rt}, 3 \mathrm{~h}$

2) SAMP

$\mathrm{CH}_{2} \mathrm{Cl}_{2}, \mathrm{rt}, 20 \mathrm{~h}$

$88 \%$

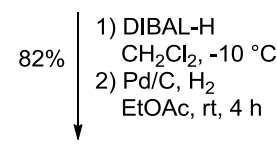

$\mathrm{RO} \bigcirc \mathrm{OH}$

35

36<smiles>C=CC(C)CC(C)C(=O)O</smiles><smiles>C=CCC(C)CC(=O)O</smiles>

Scheme 7. Synthesis of the carboxylic acid 8 by Chandrasekhar et al. TBDPS $=$ tert-butyldiphenylsilyl, Im. = imidazole, DIBAL-H = diisobutylaluminium hydride $\mathrm{IBX}=2$-iodoxybenzoic acid, SAMP $=(\mathrm{S})$-1-amino-2-methoxymethylpyrrolidine, $\mathrm{LDA}=$ lithium diisopropylamide, TBAF $=$ tetrabutylammonium fluoride, PDC = pyridinium dichromate.

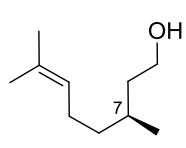

(-)-Citronellol

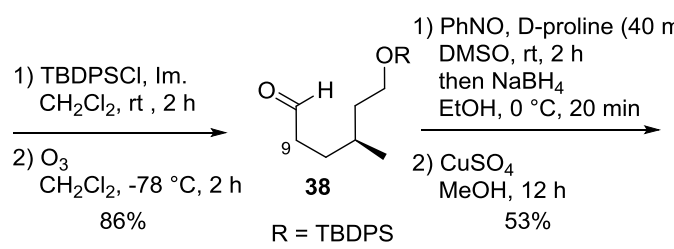

$\mathrm{R}=\mathrm{TBDPS}$

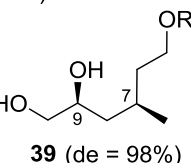

$39(\mathrm{de}=98 \%)$

\%) $\mathrm{MeOH}$

$83 \%$<smiles>C=C[C@H](C)C[C@@H](CCCCOC(C)(C)C)OC(=O)[C@H](Cc1ccccc1)N(C)C(=O)OCc1ccccc1</smiles>

44

1) TBSOTf, 2,6-lutidine

2) TBAF

THF, rt, $1 \mathrm{~h}$

3) $\mathrm{EDCl}, \mathrm{HOBt}, 8$

$\mathrm{CH}_{2} \mathrm{Cl}_{2}$, rt, $6 \mathrm{~h}$<smiles>C=C[C@H](C)C[C@@H](C)C[C@@H](C)CC(=O)N(C)[C@@H](Cc1ccccc1)C(=O)O[C@H](C)CCCCOC(C)(C)C</smiles>

45

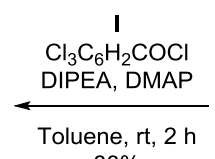

$88 \%$

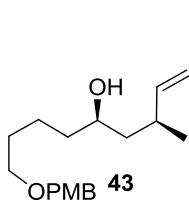

OPMB 43

$68 \%$

$$
\begin{aligned}
& \text { 1) } \mathrm{PPh}_{3}, \mathrm{I}_{2}, \mathrm{Im} \text {. } \\
& {\mathrm{MeCN} / \mathrm{Et}_{2} \mathrm{O}(3: 1)} 0^{\circ} \mathrm{C}, 20 \mathrm{~min} \\
& \hline \text { 2) } t \text {-BuOK } \\
& \mathrm{THF}, 0{ }^{\circ} \mathrm{C} \\
& \text { 3) } \mathrm{TBAF} \\
& \mathrm{THF}, \mathrm{rt}, 2 \mathrm{~h}
\end{aligned}
$$

$62 \%$

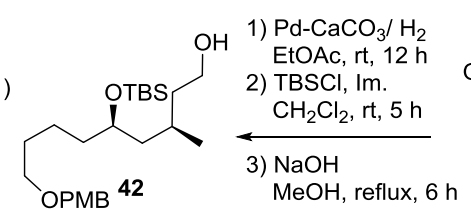

$73 \%$
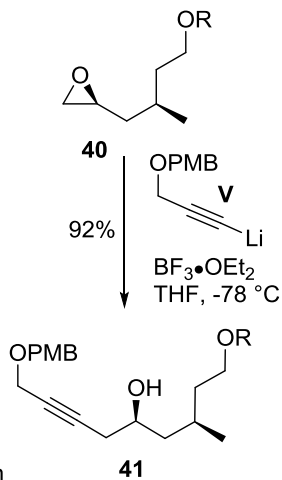

41

8. Synthesis of the C6-C13 Fragment and end game to (-)-spongidepsin by Chandrasekhar et al. TBDPS = tert-butyldiphenylsilyl, Im. = imidazole, Ts= $p-$ toluenesulfonyl, TBS $=$ tert-butyldimethylsilyl, TBAF $=$ tetrabutylammonium fluoride, DIPEA $=$ diisopropylethylamine, $\mathrm{DMAP}=$ dimethylaminopyridine, EDCI $=1$ ethyl-3-(3-dimethylaminopropyl)carbodiimide, $\mathrm{HOBt}$ = hydroxybenzotriazole 


\subsubsection{Krauss et al. Total Synthesis}

Krauss et al. have realized an efficient formal synthesis of (-)-spongidepsin by using an asymmetric anti- and synhomocrotylboration of aldehydes using optically active cyclopropylboronates to control the C2, C4, C7 and C9 stereogenic centers. ${ }^{[39]}$

Carboxylic acid $\mathbf{8}$ was prepared in four steps from acetaldehyde. After treatment of acetaldehyde with cyclopropylboronate $\mathbf{V I}$ and $\mathrm{PhBCl}_{2}$, syn $\beta$-methyl alcohol 46 was exclusively obtained with an excellent enantiomeric excess (ee $=98 \%, 78 \%$ ). After a three-step sequence, i.e. mesylation, cyanide displacement ${ }^{[40]}$ and hydrolysis of the resulting nitrile,${ }^{[41]}$ carboxylic acid $\mathbf{8}$ was isolated in $39 \%$ yield over three steps. The anti-homocrotylation of aldehyde $\mathbf{3 0}$, easily prepared from pentane-1,5-diol (85\%) ${ }^{[42]}$ with cyclopropylboronate VIII, in the presence of $\mathrm{PhBCl}_{2}$, afforded $\mathrm{C} 6-\mathrm{C} 13$ fragment 21 in $82 \%$ yield as a single anti-diastereomer with an excellent enantioselectivity (ee $=98 \%$ ). Alcohol 21 was esterified by phenylalanine derivative $\mathbf{I}$ and the final steps, to access (-)-spongidepsin, were realized according to the strategy developed by Ghosh et al. and Cossy et al. ${ }^{[7,24]}$ It is worth mentioning that cyclopropylboronates VI and VIII were synthesized in four steps, from propyne ${ }^{[39]}$ and from cis-1-bromopropene ${ }^{[43]}$ respectively, on gram scale (Scheme 9).

Synthesis of the carboxylic acid 8
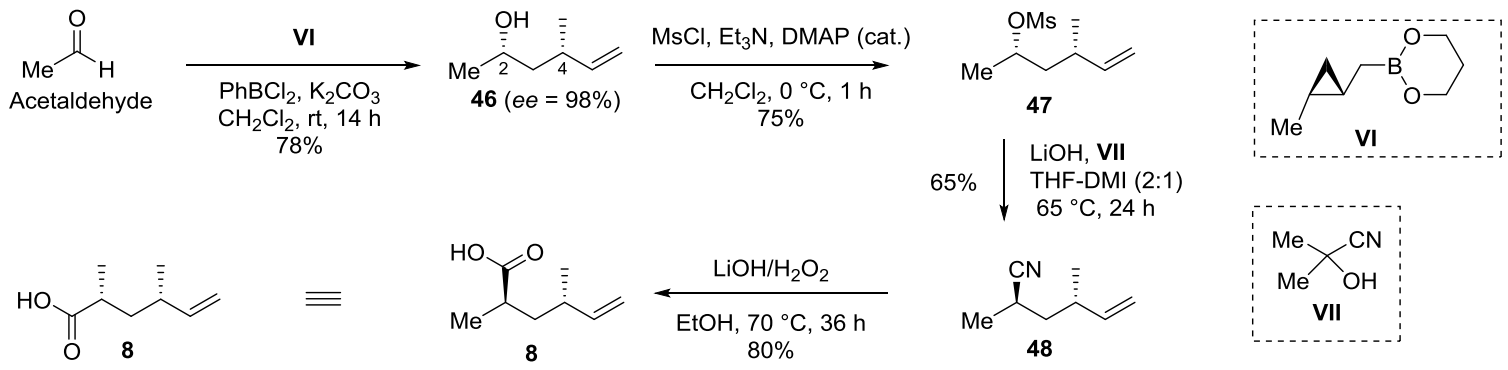

\footnotetext{
Synthesis of the C6-C13 fragment

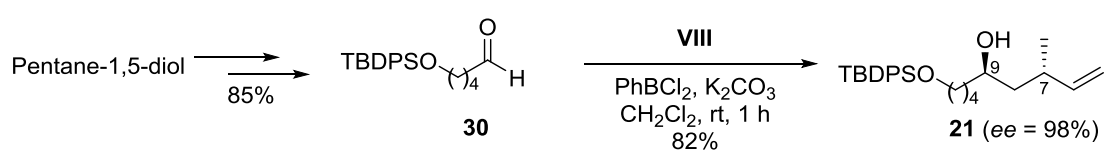

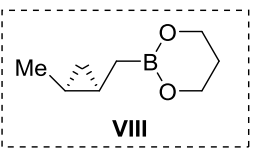

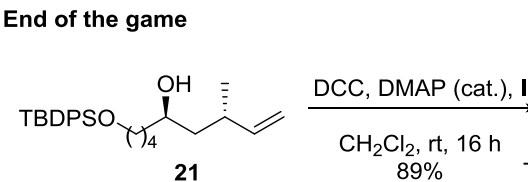

21

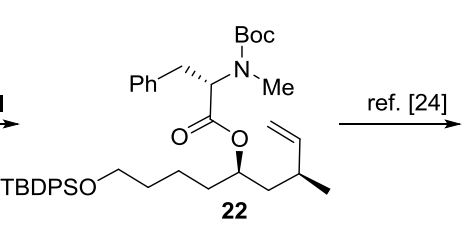

22

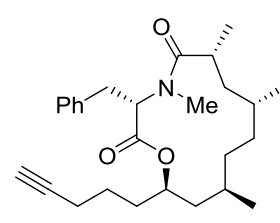

(-)-Spongidepsin

Scheme 9. Synthesis of carboxylic acid 8, C6-C13 fragment, and end of the game to (-)-spongidepsin by Krauss et al. Ms = methanesulfonyl, DMAP = dimethylaminopyridine, $\mathrm{DMI}=1,3$-dimethyl-2-imidazolidinone, $\mathrm{DCC}=$ dicyclohexylcarbodiimide.

\subsection{Control of the Stereogenic Centers by Reagents Used in Catalytic Amount}

\subsubsection{Negishi et al. Total Synthesis}

The previous syntheses of (-)-spongidepsin were achieved by using stoichiometric quantities of rather expensive chiral reagents, except for the pseudo catalytic a-hydroxylation of an aldehyde by Chandrasekhar et al. Consequently, there is some room for improvement, and Negishi et al. ${ }^{[42]}$ as well as Burgess et $a l^{[44]}$ have used chiral reagents in catalytic quantities to control three out of four stereogenic centers.

In the synthesis of (-)-spongidepsin by Negishi et al., ${ }^{[42]}$ the $\mathrm{C} 2, \mathrm{C} 4, \mathrm{C} 7$ stereogenic centers were controlled by the reagents, using the $\mathrm{Zr}$-catalyzed asymmetric carboalumination of alkenes
(ZACA reaction) ${ }^{[45-55]} \mathrm{A}$ Brown allylation (stoichiometric reagent) was performed to control the C9 stereogenic center. ${ }^{[56,57]}$ Carboxylic acid 8 was prepared from the prop-2-en-1-ol and the C6-C13 fragment from pentane-1,5-diol.

Treatment of prop-2-en-1-ol under (+)-ZACA conditions followed by the addition of iodine furnished the iodo-alcohol, ${ }^{[53}$ which was protected to give iodide $\mathbf{4 8}$ in $82 \%$ yield (ee $=82 \%$ ). At this point, this compound was transformed to an organozinc reagent and underwent a palladium-catalyzed Negishi crosscoupling with vinyl bromide to give olefin $49(88 \%) .{ }^{[50]}$ A one-pot ZACA-oxidation sequence [(+)-ZACA conditions then $\mathrm{O}_{2}$ ] led to the mono-protected diol 6 in $76 \%$ yield $(\mathrm{dr}=5.5: 1)$, and after purification by column chromatography, the diastereomeric ratio was improved to 40:1 (yield 45\%). Carboxylic acid 8 was obtained after a four step sequence (58\%): i.e. a Swern 
oxidation, Wittig olefination, deprotection, and oxidation. After

overall yield of $19 \%$ (Scheme 10). nine steps, acid 8 was obtained from prop-2-en-1-ol with an

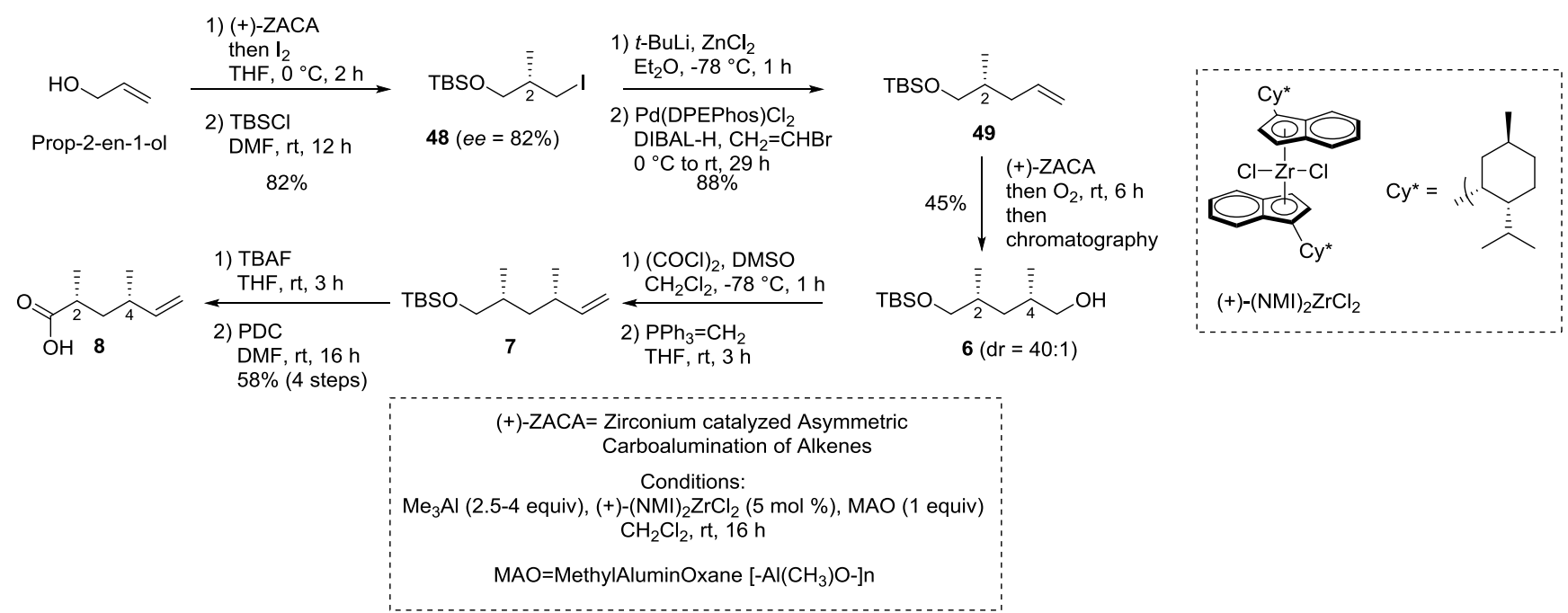

Scheme 10. Synthesis of carboxylic acid 8 by Negishi et al. TBS = tert-butyldimethylsilyl, DPEPhos = bis[(2-diphenylphosphino)phenyl] ether, DIBAL-H = diisobutylaluminium hydride, TBAF = tetrabutylammonium fluoride, $\mathrm{PDC}=$ pyridinium dichromate .

The synthesis of the $\mathrm{C} 6-\mathrm{C} 13$ fragment started with the protection/oxidation of pentane-1,5-diol and the resulting aldehyde was engaged in a Brown allylation, ${ }^{[56,57]}$ which allowed the formation of homoallylic alcohol $\mathbf{5 0}$ with the control of the C9 stereogenic center (74\% over four steps). The homoallylic alcohol was then engaged in a ZACA-oxidation sequence to furnish mono-protected triol 51 in $73 \%$ yield $(\mathrm{dr}=3.5: 1)$, whose diastereoisomeric purity was improved after purification by column chromatography ( $\mathrm{dr}=40: 1,42 \%$ yield). After a three- step sequence (oxidation, reduction and Wittig olefination), fragment 21 was obtained in a $20 \%$ overall yield from pentane1,5-diol.

The final fragment assembly to access (-)-spongidepsin closely followed the strategy developed by Ghosh et al. and Cossy et al. ${ }^{[7,24]}$ However to produce intermediate 22, the esterification of I by alcohol $\mathbf{2 1}$ was performed with DCC and thus with retention of configuration (Scheme 11).

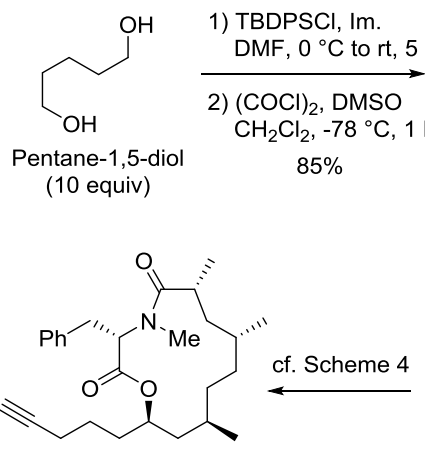

(-)-Spongidepsin<smiles>CCCCCCCCCCCCCCCCCCCCCCCC=O</smiles><smiles>C=C[C@H](C)C[C@H](CCCCOC(=O)OCc1ccccc1)OC(=O)[C@@H](Cc1ccccc1)N(C)C(=O)OC(C)(C)C</smiles>

22

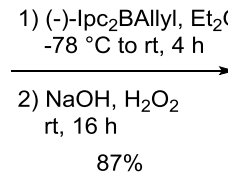

$\%$

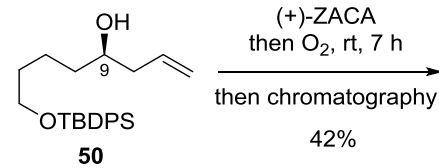

50

$42 \%$

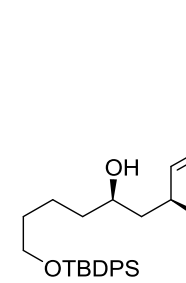

21

1) DIBAL-H

$\mathrm{CH}_{2} \mathrm{Cl}_{2},-78{ }^{\circ} \mathrm{C}$

$\frac{\text { I, DCC, DMAP (cat.) }}{\mathrm{CH}_{2} \mathrm{Cl}_{2}, \mathrm{rt}, 16 \mathrm{~h}}$

$89 \%$

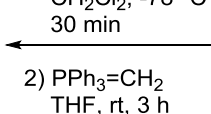

$73 \%$
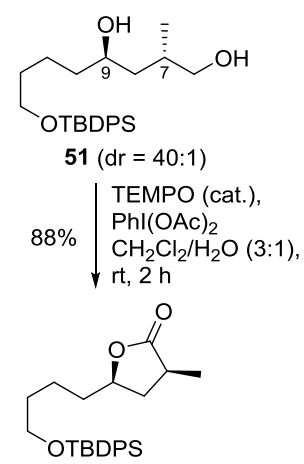

20

Scheme 11. Synthesis of the C6-C13 fragment by Negishi et al. TBDPS = tert-butyldiphenylsilyl, Im. = imidazole, DIBAL-H = diisobutylaluminium hydride, DCC = dicyclohexylcarbodiimide

\subsubsection{Burgess et al. Total Synthesis}

Burgess et al. ${ }^{[44]}$ controlled the C4 and C7 stereogenic centers by a catalytic asymmetric hydrogenation ${ }^{[58,59]}$ of acyclic allylic alcohols and the control of the C9 stereogenic center was realized by using a Sharpless kinetic resolution of an allylic alcohol. ${ }^{[60,61]}$
The synthesis of carboxylic acid $\mathbf{8}$ was achieved in 9 steps, and the C2 stereogenic center was installed from Roche ester, used as starting material. ${ }^{[62-64]}$ After a three-step sequence, i.e. protection, selective reduction with DIBAL-H, and Still-Gennari olefination, ${ }^{[65]}(Z)$ - $\alpha, \beta$-unsaturated ester $\mathbf{5 2}$ was isolated in $46 \%$ yield. To access allylic alcohol $\mathbf{5 3}$, ester $\mathbf{5 2}$ was reduced with DIBAL-H. Then, by using the iridium-carbene complex $(R)$ cat. ${ }^{[58,59]}$ under 50 bar of hydrogen, $\mathbf{5 3}$ was reduced to $\mathbf{6}$ with an 
excellent yield (93\%) and a high diastereoselectivity $(\mathrm{dr}=34: 1)$. This latter was even further increased after purification $(d r=$ 120:1). Mono-protected diol 6 was then transformed to carboxylic acid 8 after a Swern oxidation, a Wittig olefination, a deprotection and a final oxidation (Scheme 12).<smiles>COC(=O)C(C)CO</smiles>

(+)-Roche ester

1) TBDPSCl, Im.

DMF, rt, $8 \mathrm{~h}$

2) DIBAL-H

$\underset{\substack{\text { 3) } \\ \mathrm{THF},-78^{\circ} \mathrm{C}, 3 \mathrm{~h}}}{\stackrel{\mathrm{Et}_{2} \mathrm{O},-78^{\circ} \mathrm{C}, 20 \mathrm{~min}}{\longrightarrow}}$

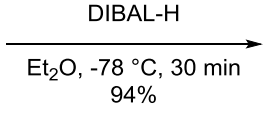

$\overbrace{(Z)-53}^{\mathrm{RO}} \overbrace{\mathrm{OH}}$

$46 \%$

$$
R=T B D P S
$$<smiles>CC(C=CC=CC(C)C(=O)O[Na])CC(C)C(=O)O</smiles><smiles>[R9]CC(C)CC(C)C=C</smiles>

1) $(\mathrm{COCl})_{2}$, DMSO

$\mathrm{CH}_{2} \mathrm{Cl}_{2},-78^{\circ} \mathrm{C}, 1 \mathrm{~h}$

2) $\mathrm{PH}_{3}=\mathrm{CH}_{2}$

$\mathrm{THF}, 0^{\circ} \mathrm{C}, 1 \mathrm{~h}$

$87 \%$

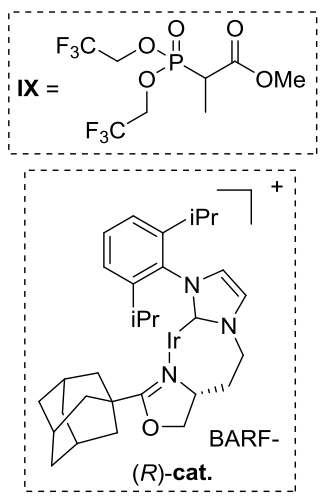

Scheme 12. Synthesis of the carboxylic acid 8 by Burgess et al. TBDPS $=$ tert-butyldiphenylsilyl, Im. $=$ imidazole, DIBAL-H = diisobutylaluminium hydride, HMDS $=$ hexamethyldisilazane, TBAF = tetrabutylammonium fluoride, TEMPO $=(2,2,6,6$-tetramethylpiperidin-1-yl)oxyl.

To obtain the optically active allylic alcohol $(R)-54$ (control of the C9 stereogenic center) from racemic alcohol 54, prepared in three steps from pentane-1,5-diol $(78 \%),{ }^{[66]}$ a Sharpless kinetic resolution was used $(46 \%$, ee $>98 \%)]{ }^{[60,61]}$ Allylic diol 55 was then prepared in five steps from $(R)-54$ (i.e. acylation, oxidative cleavage, Wittig reaction, DIBAL-H reduction and protection, $73 \%$ over five steps). Hydrogenation of compound $\mathbf{5 5}$ under 50 bar of hydrogen in the presence of the iridium carbene complex (S)-cat. afforded, after deprotection, diol 56 with a high diastereoselectivity $(97 \%, \mathrm{dr}=61: 1) .{ }^{[67]}$ This mono-protected triol was then transformed to $\mathbf{4 3}$ in three routine steps (i.e. selective oxidation, reduction, and Wittig olefination, 66\% over three steps). The synthesis of (-)-spongidepsin was completed by assembling the three fragments I, 8 and $\mathbf{4 3}$ according to the strategy reported by Chandrasekhar et al., ${ }^{[30]}$ and by Ghosh and $\mathrm{Xu}^{[7]}$ for the last steps. It is worth mentioning that the esterification of carboxylic acid $\mathbf{8}$ with intermediate $\mathbf{4 4}$ was realized with PyBOP (benzotriazol-1-yl-oxytripyrrolidinophosphonium hexafluorophosphate) and DIPEA (Scheme 13).

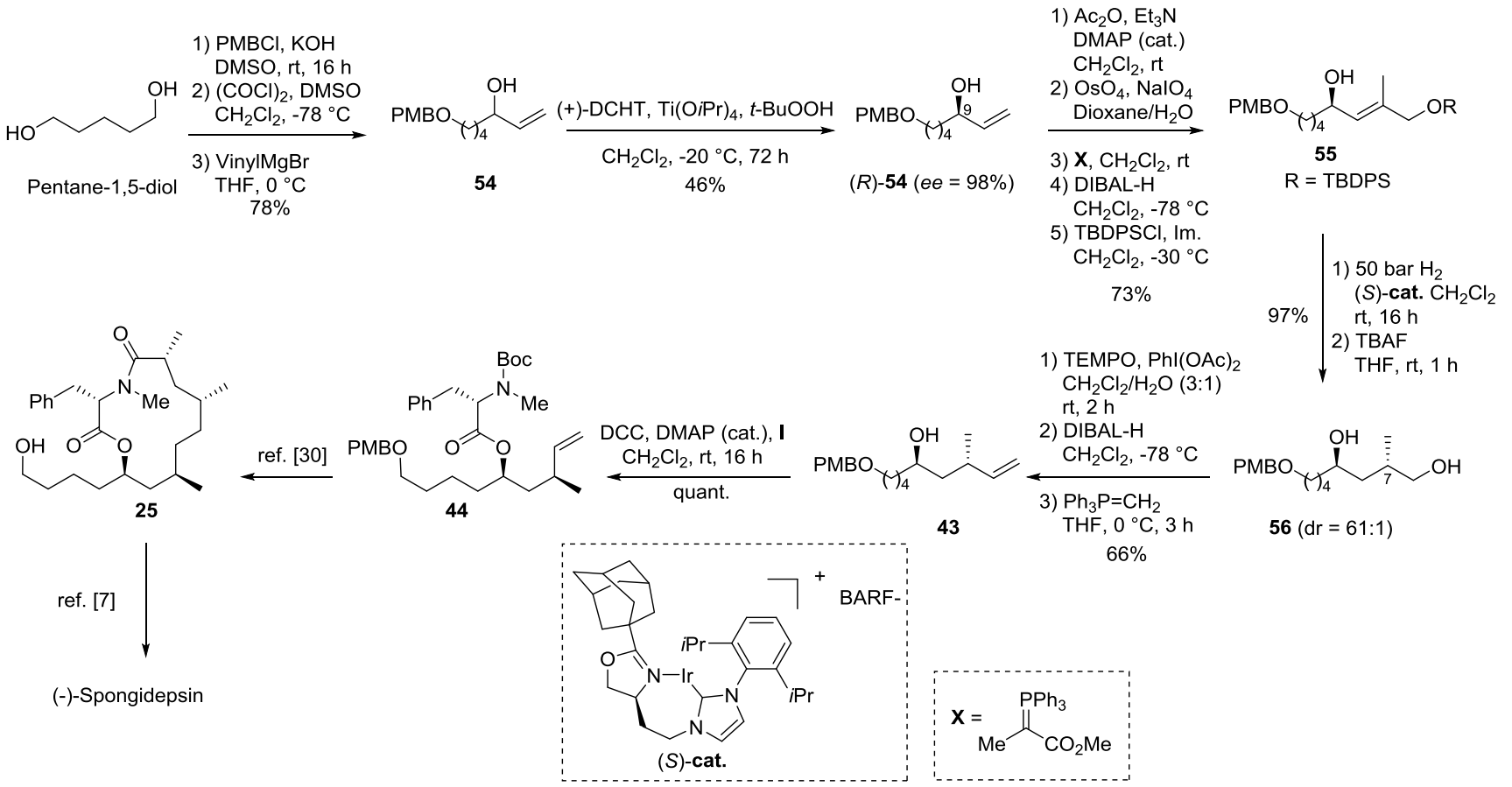

Scheme 13. Synthesis of the $\mathrm{C} 6-\mathrm{C} 13$ fragment by Burgess et al. DCHT = dicyclohexyl tartrate, $\mathrm{DMAP}=$ dimethylaminopyridine, $\mathrm{DIBAL}-\mathrm{H}=$ diisobutylaluminium hydride, TBDPS = tert-butyldiphenylsilyl, Im. = imidazole, TBAF = tetrabutylammonium fluoride, TEMPO = $(2,2,6,6$-tetramethylpiperidin-1-yl)oxyl, BARF = tetrakis[3,5-bis(trifluoromethyl)phenyl]borate. 


\section{Synthesis of Analogues}

Forsyth et al. have synthesized seven spongidepsin diastereomers $^{[6]}$ and Ghosh et al. ${ }^{[7]}$ four diastereomers but, surprisingly, these compounds were not tested for their biological activity. On the contrary, Burgess et al. have synthesized four spongidepsin derivatives A9-A12 (Scheme 12), which were tested in vitro for their antiproliferative activity on human embryonic kidney cells (5HEK-293). However A9 and A10 are just as cytotoxic as the natural product and A11 and
A12 did not show any significant toxicities in the same concentration range. In their approach towards the synthesis of (+)-spongidepsin, Rao et al. ${ }^{[68]}$ synthesized $\mathbf{A} 13$ from D-mannitol and (+)- $\beta$-citronellene using two Evans asymmetric methylations to control the C2 and C9 stereogenic centers, a Mitsunobu esterification, a PyBOP-mediated amide formation. When a RCM was applied to A13 after protection of the triple bond, macrocycle A14 was directly isolated. It is worth mentioning that no biological tests were reported for A14 (Scheme 14).

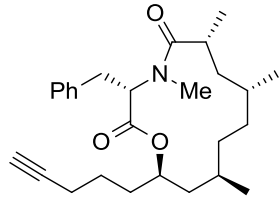

(-)-Spongidepsin

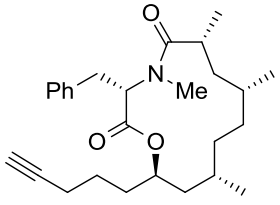

A1, Forsyth

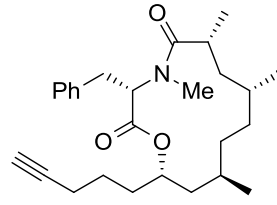

A2, Forsyth and Ghosh

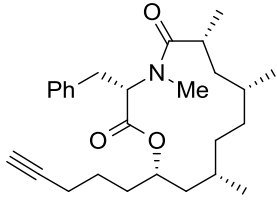

A3, Forsyth

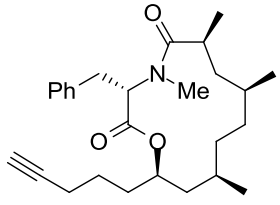

A4, Forsyth and Ghosh<smiles>C#CCCC[C@H](C[C@@H](C)CC[C@H](C)CC(C)C(=O)N(C)[C@H](Cc1ccccc1)C(=O)O)OC</smiles>

A5, Forsyth and Ghosh

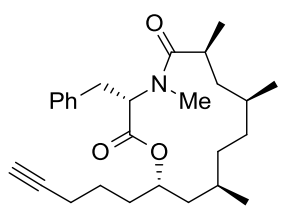

A6, Forsyth and Ghosh

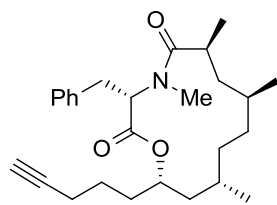

A8, Forsyth

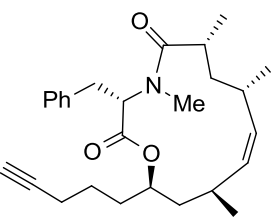

A9, Burgess<smiles>CCCCC(CCC)CCC(C)C(C)C(=O)N(Cc1ccccc1)C(=O)C(C)C</smiles>

A10, Burgess

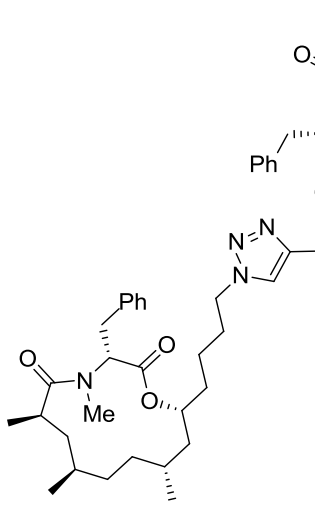

A11, Burgess

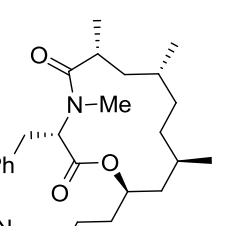

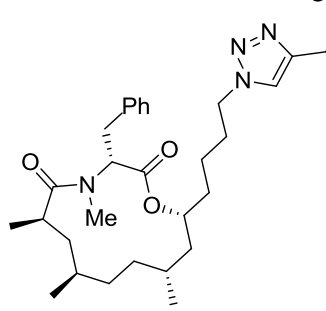

A12, Burgess

Scheme 14. Spongidepsin analogs A1-A14

\section{Comparison of the Syntheses and Conclusions}

In summary, seven syntheses of (-)-spongidepsin have been reported in the literature. In all cases, the same global retrosynthetic approach was used, inspired from the pioneering reports by Forsyth et al. and Ghosh and Xu. The syntheses mainly differ from the reactions selected to control the four of the five stereogenic centers, one of them being always introduced by (S)-phenylalanine. Table 1 outlines the different stereoselective reactions used for their control in the different syntheses of (-)-spongidepsin. The synthesis of carboxylic acid 8 by Krauss et al. is the most efficient in terms of steps and the synthesis realized by Burgess et al. is the most efficient in terms of overall yield. By far, the synthesis of the $\mathrm{C} 6-\mathrm{C} 13$ fragment by
Krauss et al. is the most efficient in terms of steps and overal yield, however the cyclopropaneboronates have to be prepared in four to five steps from commercially available starting materials (Table 2). There is still room for improvement to achieve the synthesis of (-)-spongidepsin. Particularly, it would be important to know the biological mode of action of this natural product in order to design potent bioactive analogs and to design efficient and flexible syntheses to access them. 
Table 1. Control of the stereogenic centers by the different research groups

\begin{tabular}{|c|c|c|c|c|c|}
\hline Authors & $\mathrm{C} 2$ & $\mathrm{C} 4$ & $\mathrm{C7}$ & $\mathrm{C9}$ & Ref. \\
\hline Forsyth et al. & Enzymatic resolution & Enzymatic resolution & Hydroboration & Epoxide opening & [6] \\
\hline Ghosh et al. & Enzymatic resolution & Enzymatic resolution & Evans alkylation & Bromo- lactonisation & [7] \\
\hline Cossy et al. & Roche ester & Crotyl- stannylation & alkylation & $\mathrm{Sml}_{2}$-mediated radical addition & [24] \\
\hline $\begin{array}{l}\text { Chandrasekhar } \\
\text { et al. }\end{array}$ & Roche ester & Enders alkylation & (-)-Citronellol & Proline-catalyzed $\alpha$-hydroxylation & [30] \\
\hline Krauss et al. & Homocrotylboration & Homocrotylboration & Homocrotylboration & Homocrotylboration & [39] \\
\hline Negishi et al. & ZACA & ZACA & ZACA & Allylboration & [42] \\
\hline Burgess et al. & Roche ester & $\begin{array}{l}\text { Asymmetric } \\
\text { hydrogenation }\end{array}$ & $\begin{array}{l}\text { Asymmetric } \\
\text { hydrogenation }\end{array}$ & Sharpless kinetic resolution & [44] \\
\hline
\end{tabular}

Table 2. Number of steps and overall yields for the synthesis of carboxylic acid 8, fragment C6-C11 or C6-C13 from the reported starting materials.

\begin{tabular}{|c|c|c|c|c|}
\hline Authors & Carboxylic acid 8 & Fragment $\mathrm{C} 6-\mathrm{C} 11$ & Fragment $\mathrm{C} 6-\mathrm{C} 13$ & Ref. \\
\hline Forsyth et al. & $\begin{array}{l}\text { Mono-acetylated diol } 5 \\
6 \text { steps, } 30 \%\end{array}$ & $\begin{array}{l}\text { Epoxyde } 9 \\
7 \text { steps, } 58 \%\end{array}$ & - & {$[6]$} \\
\hline Ghosh et al. & $\begin{array}{l}\text { Mono-acetylated diol } 5 \\
6 \text { steps, } 30 \%\end{array}$ & - & $\begin{array}{l}\text { Pent-4-en-1-ol } \\
8 \text { steps, } 35 \%\end{array}$ & [7] \\
\hline Cossy et al. & $\begin{array}{l}\text { Roche ester } \\
7 \text { steps, } 31 \%\end{array}$ & - & $\begin{array}{l}5 \text {-Hexen-1-ol } \\
6 \text { steps, } 11 \%\end{array}$ & [24] \\
\hline $\begin{array}{l}\text { Chandrasekhar } \\
\text { et al. }\end{array}$ & $\begin{array}{l}\text { Roche ester } \\
7 \text { steps, } 29 \%\end{array}$ & - & $\begin{array}{l}(-) \text {-Citronellol } \\
13 \text { steps, } 16 \%\end{array}$ & [30] \\
\hline Krauss et al. & $\begin{array}{l}\text { Acetaldehyde } \\
4 \text { steps } 30 \%\end{array}$ & - & $\begin{array}{l}\text { Pentane-1,5-diol } \\
3 \text { steps, } 70 \%\end{array}$ & [39] \\
\hline Negishi et al. & $\begin{array}{l}\text { Propen-2-en-1-ol } \\
9 \text { steps, } 19 \%\end{array}$ & - & $\begin{array}{l}\text { Pentane-1,5-diol } \\
8 \text { steps, } 20 \%\end{array}$ & [42] \\
\hline Burgess et al. & $\begin{array}{l}\text { Roche ester } \\
9 \text { steps, } 28 \%\end{array}$ & - & $\begin{array}{l}\text { Pentane-1,5-diol } \\
14 \text { steps, } 17 \%\end{array}$ & [44] \\
\hline
\end{tabular}

\section{Acknowledgements}

Two of us, L. F. and O. P. thank the MESRI for a PhD grant.

Keywords: structural determination - total synthesis • asymmetric synthesis $\cdot$ synthetic strategy $\cdot$ polyketide $\bullet$ macrolide

[1] A. Grassia, I. Bruno, C. Debitus, S. Marzocco, A. Pinto, L. GomezPaloma, R. Riccio, Tetrahedron 2001, 57, 6257-6260.

[2] R. Kazlauskas, P. T. Murphy, R. J. Wells, K. Noack, W. E. Oberhansli, P. A. Schonholzer, Aust. J. Chem. 1979, 32, 867-880.
[3] G. R. Pettit, Z. A. Chicacz, F. Gao, C. L. Herald, M. R. Boyd, J. M. Schmidt, J. N. A. Hooper, J. Org. Chem. 1993, 58, 1302-1304.

[4] P. Marfey, Carlsberg Res. Commun. 1984, 49, 591.

[5] N. Matsumori, D. Kaneno, M. Murata, H. Nakamura, K. Tachibana, J. Org. Chem. 1999, 64, 866-876.

[6] J. Chen, C. J. Forsyth, Angew. Chem. Int. Ed. 2004, 43, 2148-2152.

[7] A. K. Ghosh, X. Xu, Org. Lett. 2004, 6, 2055-2058.

[8] N. L. Allinger, J. Am. Chem. Soc. 1959, 81, 232-236.

[9] L. A. Paquette, S. L. Boulet, Synthesis 2002, 888-894.

[10] G.-Q. Lin, W.-C. Xu, Tetrahedron 1996, 52, 5907-5912.

[11] L. Lombardo, L. Tetrahedron Lett. 1982, 23, 4293-4296.

[12] R. D. Cink, C. J. Forsyth, J. Org. Chem. 1995, 60, 8122-8123.

[13] W. P. Griffith, S. V. Ley, J. Chem. Soc., Chem. Commun. 1987, No. 21, 1625-1627. 
[14] O. Mitsunobu, Synthesis 1981, 1981, 1-28.

[15] F. Albericio, M. Cases, J. Alsina, S. A. Triolo, L. A. Carpino, S. A. Kates, Tetrahedron Lett. 1997, 38, 4853-4856.

[16] T. M. Trnka, R. H. Grubbs, Acc. Chem. Res. 2001, 34, 18-29.

[17] S. Müller, B. Liepold, G. J. Roth, H. J. Bestmann, Synlett 1996, 521-522.

[18] K. Fujita, K. Mori, Eur. J. Org. Chem. 2001, 493-502.

[19] B. Liu, S. K. Das, R. Roy, Org. Lett. 2002, 4, 2723-2726.

[20] D. A. Evans, J. M. Takacs, L. R. McGee, M. D. Ennis, D. J. Mathre, J. Bartroli, Pure Appl. Chem. 1981, 53, 1109-1127.

[21] R. H. Bradbury, J. M. Revill, J. E. Rivett, D. Waterson, D. A., Tetrahedron Lett. 1989, 30, 3845-3848.

[22] D. Crich, S. Sun, S. J. Org. Chem. 1996, 61, 7200-7201.

[23] S. Ohira, S. Synth. Comm. 1989, 19, 561-564.

[24] L. Ferrié, S. Reymond, P. Capdevielle, J. Cossy, Org. Lett. 2006, 8, 3441-3443.

[25] BV. A. Johns, C. M. Grant, J. A. Marshall, Org. Synth. 2002, 79, 59.

[26] G. E. Keck, K. A. Savin, E. N. K. Cressman, D. E. Abbott, J. Org. Chem. 1994, 59, 7889-7896.

[27] Y.-S. Hon, S.-W. Lin, L. Lu, Y.-J. Chen, Tetrahedron 1995, 51, 5019-5034.

[28] Synthesized from (+)- $N$-methylephedrine.

[29] S. Fukuzawa, K. Seki, M. Tatsuzawa, K. A. Mutoh, K.A F J. Am. Chem. Soc. 1997, 119, 1482-1483.

[30] S. Chandrasekhar, S. R. Yaragorla, L. Sreelakshmi, C. R. Reddy, Tetrahedron 2008, 64, 5174-5183.

[31] D. Enders, H. Eichenauer, Chem. Ber. 1979, 112, 2933-2960.

[32] I. K. Mangion, D. W. C. MacMillan, J. Am. Chem. Soc. 2005, 127, 3696-3697.

[33] G. N. Varseev, M. E. Maier, Org. Lett. 2007, 9, 1461-1464.

[34] S. P. Brown, M. P. Brochu, C. J. Sinz, D. W. C. MacMillan, J. Am. Chem. Soc. 2003, 125, 10808-10809.

[35] K. C. Nicolaou, P. K. Sasmal, H. Xu, K. Namoto, A. Ritzén, Angew. Chem. Int. Ed. 2003, 42, 4225-4229.

[36] Y. Hayashi, J. Yamaguchi, K. Hibino, M. Shoji, Tetrahedron Lett. 2003, 44 (45), 8293-8296.

[37] S. Hatakeyama, H. Irie, T. Shintani, Y. Noguchi, H. Yamada, M. Nishizawa, Tetrahedron 1994, 50, 13369-13376.

[38] J. Inanaga, K. Hirata, H. Saeki, T. Katsuki, M. Yamaguchi, BCSJ 1979, 52, 1989-1993.

[39] H. Lin, L. Tian, I. J. Krauss, J. Am. Chem. Soc. 2015, 137, 1317613182.

[40] T. Hasegawa, Y. Kawanaka, E. Kasamatsu, C. Ohta, K. Nakabayashi, M. Okamoto, M. Hamano, K. Takahashi, S. Ohuchida, Y. Hamada, Org. Process Res. Dev. 2005, 9, 774-781.

[41] M. Rössle, D. J. Del Valle, M. J. Krische, Org. Lett. 2011, 13, 14821485.

[42] G. Zhu, E. Negishi, E. Org. Lett. 2007, 9, 2771-2774.
[43] C. E. Fuller, D. G. Walker, J. Org. Chem. 1991, 56, 4066-4067.

[44] Y. Zhu, A. Loudet, K. Burgess,. Org. Lett. 2010, 12, 4392-4395.

[45] D. Y. Kondakov, E. Negishi, J. Am. Chem. Soc. 1995, 117, 1077110772

[46] D. Y. Kondakov, E. Negishi, J. Am. Chem. Soc. 1996, 118, 15771578.

[47] S. Huo, E. Negishi, Org. Lett. 2001, 3, 3253-3256.

[48] S. Huo, J. Shi, E. Negishi,. Angew. Chem. Int. Ed. 2002, 41, $2141-$ 2143.

[49] E. Negishi, Z. Tan, B. Liang, T. Novak, T. Proc. Natl. Acad. Scl. 2004, 101, 5782-5787.

[50] Z. Tan, E. Negishi, Angew. Chem. Int. Ed. 2004, 43, 2911-2914.

[51] M. Magnin-Lachaux, Z. Tan, B. Liang, E. Negishi, Org. Lett. 2004, 6 , 1425-1427.

[52] T. Novak, Z. Tan, B. Liang B., E. Negishi, J. Am. Chem. Soc. 2005 127, 2838-2839.

[53] B. Liang, T. Novak, Z. Tan, E. Negishi, J. Am. Chem. Soc. 2006 128, 2770-2771.

[54] Z. Tan, B. Liang, S. Huo, J. Shi, E. Negishi, Tetrahedron Asymmetry 2006, 17, 512-515.

[55] Z. Huang, Z. Tan, T. Novak, G. Zhu, E. Negishi, Adv. Synth. Catal. 2007, 349, 539-545.

[56] H. C. Brown, P. K. Jadhav, J. Am. Chem. Soc. 1983, 105, 2092 2093.

[57] P. V. Ramachandran, M. V. R. Reddy, H. C. Brown, Pure Appl. Chem. 2003, 75, 1263-1275

[58] M. T. Powell, D.-R. Hou, M. C. Perry, X. Cui, K. Burgess, J. Am Chem. Soc. 2001, 123, 8878-8879.

[59] M. C. Perry, X. Cui, M. T. Powell, D.-R. Hou, J. H. Reibenspies, K Burgess, J. Am. Chem. Soc. 2003, 125, 113-123.

[60] Y. Gao, J. M. Klunder, R. M. Hanson, H. Masamune, S. Y. Ko, K. B. Sharpless, J. Am. Chem. Soc. 1987, 109, 5765-5780.

[61] A. Pfenninger, Synthesis 1986, 89-116.

[62] J. Zhou, Y. Zhu, K. Burgess, Org. Lett. 2007, 9, 1391-1393.

[63] J. Zhou, J. W. Ogle, Y. Fan, V. Banphavichit(Bee), Y. Zhu, K. Burgess, Chem. Eur. J 2007, 13, 7162-7170.

[64] J. Zhou, K. Burgess, Angew. Chem. Int. Ed. 2007, 46, 1129-1131.

[65] F. Yokokawa, T. Asano, T. Shioiri, Tetrahedron 2001, 57, 63116327.

[66] C. M. Grisé, G. Tessier, L. Barriault, Org. Lett. 2007, 9, 1545-1548.

[67] Y. Zhu, K. Burgess, J. Am. Chem. Soc. 2008, 130, 8894-8895.

[68] G. Venkateswar Reddy, R. Satish Chandra Kumar, G. Shankaraiah K. Suresh Babu, J. Madhusudana Rao, Helv. Chim. Acta 2013, 96, 1590-1600. 


\section{Entry for the Table of Contents: Total Synthesis}

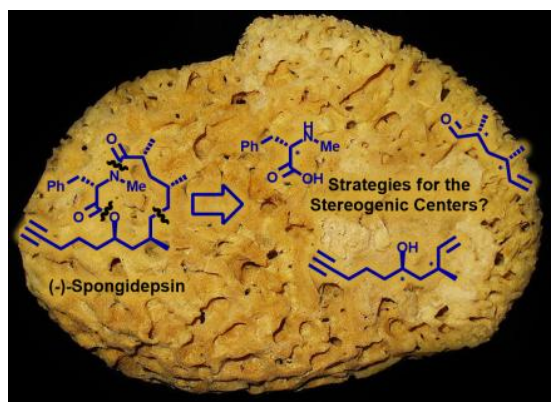

Spongidepsin is a macrolide isolated from Spongia sp. Due to its original structure, exhibiting a phenylalanine amino acid moiety in a macrocyle and the presence of a terminal alkyne, associated to its antiproliferative activity, the molecule has attracted synthetic chemists culminating in seven total and/or formal syntheses. The major differences in the syntheses rely on the methods use to synthesize the $\mathrm{C} 1-\mathrm{C} 5$, the $\mathrm{C} 6-\mathrm{C} 11$ or $\mathrm{C} 6-13$ fragments as their connectivities to access spongidepsin are similar. The different methods to synthesize spongidepsin are compared. 